\title{
PERKEMBANGAN KEWENANGAN PEMBATALAN PERATURAN DAERAH DAN PERATURAN KEPALA DAERAH
}

Kajian Putusan Mahkamah Konstitusi Nomor 137/PUU-XIII/2015

dan Nomor 56/PUU-XIV/2016

\section{DEVELOPMENT OF REGULATORY AUTHORITY ANNULMENT OF LOCAL REGULATIONS AND REGIONAL HEAD REGULATIONS}

\author{
An Analysis of Constitutional Court Decision \\ Number 137/PUU-XIII/2015 and Number 56/PUU-XIV/2016 \\ Eka NAM Sihombing \\ Fakultas Hukum Universitas Muhammadiyah Sumatera Utara \\ Jl. Kapten Muchtar Basri No. 3, Medan 20238 \\ E-mail: ekahombing@gmail.com
}

Naskah diterima: 28 April 2017; revisi: 15 Agustus 2017; disetujui 15 Agustus 2017

\section{ABSTRAK}

Putusan Nomor 137/PUU-XIII/2015 menyatakan Pasal 251 Undang-Undang Nomor 23 Tahun 2014 tentang Pemerintahan Daerah terkait dengan kewenangan pembatalan peraturan daerah kabupaten/kota tidak lagi bisa dibatalkan Menteri Dalam Negeri atau gubernur. Melengkapi putusan tersebut, Mahkamah Konstitusi melalui Putusan Nomor 56/PUU-XIV/2016 menyatakan pemerintah pusat juga tidak lagi memiliki kewenangan untuk melakukan pembatalan peraturan daerah provinsi. Putusan tersebut tidak serta merta menyelesaikan persoalan terkait dengan kewenangan pembatalan peraturan daerah, hal ini dikarenakan putusan Mahkamah Konstitusi hanya berlaku bagi peraturan daerah provinsi dan peraturan daerah kabupaten/kota. Rumusan masalah yang akan diurai dalam tulisan ini adalah bagaimana kewenangan pembatalan peraturan daerah dan peraturan kepala daerah oleh Menteri dan gubernur pasca Putusan Nomor 137/PUU-XIII/2015 dan Nomor 56/PUU$\mathrm{XIV} / 2016$. Metode yang digunakan dalam penelitian ini adalah metode penelitian yuridis normatif. Hasil penelitian menunjukkan bahwa dalam negara dengan bentuk kesatuan memang sudah sepatutnya pemerintah yang tingkatannya lebih tinggi diberikan kewenangan
\end{abstract}

untuk melakukan pengawasan terhadap regulasi yang lahir di daerah. Implementasi dari pengawasan tersebut dapat dilakukan dengan melakukan pembinaan kepada daerah melalui penguatan executive preview atau pengujian terhadap suatu norma hukum sebelum sah mengikat secara umum, hal ini sejalan dengan ruh ketentuan Pasal 24A UUD NRI 1945.

Kata kunci: pembatalan, peraturan daerah, peraturan kepala daerah.

\section{ABSTRACT}

Constitutional Court Decision Number137/PUUXIII/2015 stated in Article 251 of Law Number 23 of 2014 on Local Government related to the issue if regulatory authority annulment of local and leaders regulations can no longer be withdrawn by the Minister of Home Affairs or Governor. Completing the decision, the Constitutional Court through Decision Number 56/ PUU-XIV/2016 stated that the Central Government also no longer has the authority to annul the Provincial Regulation. The Constitutional Court Decision does not necessarily solve the problems related to the authority annulment of the local regulations. This is because 
the Constitutional Court Decision only applies to the Provincial Regulation and District/City Regulation. The formulation of the problems elaborated through this analysis is how the Authority Annulment of Regional Regulation by the Minister and the Governor after the issuance of Court Decision Number 137/PUUXIII/2015 and Constitutional Court Decision Number 56/PUU-XIV/2016. This analysis makes use of the legal juridical normative research method. The results show that in a state of unity it is appropriate that higher levels of government are given the authority to supervise the regulations set in the regions. The supervision can be implemented by conducting such a guidance to the region through the strengthening of executive preview or legal norm review before it is legally binding in general. This is in line with the spirit of Article 24A of the 1945 Constituition of the Republic of Indonesia.

Keywords: annulment, local regulation, regional head regulation.

\section{PENDAHULUAN}

\section{A. Latar Belakang}

Ketentuan Undang-Undang Nomor 23 Tahun 2014 tentang Pemerintahan Daerah, secara eksplisit memberikan kewenangan bagi Menteri Dalam Negeri dan gubernur secara berjenjang untuk membatalkan peraturan daerah dan peraturan kepala daerah yang bertentangan dengan peraturan perundang-undangan yang lebih tinggi, kepentingan umum dan/atau kesusilaan. Pembatalan suatu peraturan daerah merupakan kewenangan pemerintah dalam kaitannya melaksanakan proses pengawasan kepada daerah (Budiputra, 2015: 4).

Pengawasan terhadap peraturan daerah maupun peraturan kepala daerah ini lahir dari kewenangan pengawasan pemerintah pusat terhadap penyelenggaraan pemerintah daerah dalam kerangka Negara Kesatuan Republik Indonesia khususnya mengenai peraturan yang dibuat daerah. Namun dalam sidang pleno Mahkamah Konstitusi yang terbuka untuk umum pada tanggal 5 April 2017, melalui Putusan Nomor 137/PUU-XIII/2015 menyatakan Pasal 251 Undang-Undang Nomor 23 Tahun 2014 tentang Pemerintahan Daerah terkait dengan kewenangan pembatalan peraturan daerah kabupaten/kota tidak lagi bisa dibatalkan Menteri Dalam Negeri atau gubernur.

Mahkamah Konstitusi dalam amar putusannya menyatakan bahwa frase "peraturan daerah kabupaten/kota dan" dalam ketentuan Pasal 251 ayat (2) dan (4), frase "peraturan daerah kabupaten/kota dan/atau" dalam Pasal 251 ayat (3), dan frase "penyelenggara pemerintahan daerah kabupaten/kota tidak dapat menerima keputusan pembatalan peraturan daerah kabupaten/kota dan" Undang-Undang Nomor 23 Tahun 2014 tentang Pemerintahan Daerah bertentangan dengan UUD NRI 1945 dan tidak mempunyai kekuatan hukum mengikat.

Putusan Mahkamah Konsttusi ini tidak bulat, karena diwarnai dengan pendapat berbeda (dissenting opinion) dari empat hakim konstitusi yang menolak mencabut kewenangan Menteri Dalam Negeri dalam membatalkan peraturan daerah. Alasannya, dalam otonomi daerah, tanggung jawab penyelenggaraan pemerintah berakhir di presiden. Selanjutnya, melengkapi Putusan Nomor 137/PUU-XIII/2015, Mahkamah Konstitusi melalui Putusan Nomor 56/PUUXIV/2016 menyatakan pemerintah pusat tidak lagi memiliki kewenangan untuk melakukan pembatalan peraturan daerah provinsi. 
Putusan tersebut tidak serta merta menyelesaikan persoalan terkait dengan kewenangan pemerintah dalam produk hukum daerah, hal ini dikarenakan putusan Mahkamah Konstitusi hanya berlaku bagi peraturan daerah provinsi dan peraturan daerah kabupaten/kota, sedangkan peraturan kepala daerah (peraturan gubernur dan peraturan bupati/wali kota), gubernur maupun Menteri Dalam Negeri masih berwenang membatalkannya. Mahkamah Konstitusi berpendapat dalam pertimbangannya bahwa:

"...oleh karena peraturan kepala daerah merupakan salah satu jenis peraturan perundang-undangan berdasarkan Pasal 8 ayat (2) Undang-Undang Nomor 12 Tahun 2011, akan tetapi oleh karena dibentuk oleh kepala daerah sebagai satuan bestuur yang lebih tinggi memiliki kewenangan untuk membatalkan peraturan kepala daerah. Pembatalan dan mekanisme pengajuan keberatan pembatalan peraturan kepala daerah dalam Undang-Undang Pemerintah Daerah merupakan bagian dari mekanisme pengajuan keberatan pembatalan peraturan kepala daerah dalam Undang-Undang Pemerintah Daerah merupakan bagian dari mekanisme pengawasan dari presiden atau menteri dan gubernur sebagai wakil pemerintah pusat kepada pemerintah daerah atau dengan kata lain sebagai suatu bentuk pengawasan, bukan pengujian peraturan perundang-undangan dalam lingkungan bestuur yang lebih tinggi terhadap satuan bestuur yang lebih rendah."

Problematika kewenangan pembatalan terhadap peraturan daerah dan peraturan kepala daerah pasca putusan Mahkamah Konstitusi tersebut di atas menarik untuk dikupas lebih dalam, terutama apabila dikaitkan dengan aspek konstitusionalitas kewenangan pembatalan peraturan perundang-undangan di bawah undang-undang yang berdasarkan Pasal 24A ayat (1) UUD NRI 1945 diberikan kepada Mahkamah Agung.

\section{B. Rumusan Masalah}

Berdasarkan uraian di atas, maka dapat dirumuskan permasalahan sebagai berikut, yaitu: bagaimana kewenangan pembatalan peraturan daerah dan peraturan kepala daerah pasca Putusan Nomor 137/PUU-XIII/2015 dan Nomor 56/PUU-XIV/2016?

\section{Tujuan dan Kegunaan}

Tulisan ini bertujuan untuk menelusuri konstitusionalitas kewenangan pembatalan peraturan daerah dan peraturan kepala daerah oleh Menteri dan gubernur pasca Putusan Nomor 137/PUU-XIII/2015 dan Nomor 56/PUUXIV/2016. Lebih lanjut, tulisan ini diharapkan memiliki kegunaan sebagai berikut:

1. Secara teoritis hasil penelitian ini adalah untuk memberikan pengembangan ilmu hukum khususnya yang terkait dengan kewenangan pembatalan peraturan daerah dan peraturan kepala daerah.

2. Secara praktis, hasil penelitian ini juga akan berguna bagi kalangan praktisi, baik itu DPRD, pemerintah daerah maupun bagi siapa saja yang menaruh minat dalam bidang ini.

\section{Tinjauan Pustaka}

\section{Teori Jenjang Norma}

Kelsen mengemukakan bahwa dalam pembentukan peraturan perundang-undangan dikenal teori jenjang hukum (stufentheorie). Dalam teori tersebut Kelsen berpendapat bahwa norma-norma hukum itu berjenjang-jenjang dan berlapis-lapis dalam suatu hierarki (tata susunan) dalam arti suatu norma yang lebih tinggi berlaku, 
bersumber dan berdasar pada norma yang lebih tinggi lagi, demikian seterusnya sampai pada suatu norma yang tidak dapat ditelusuri lebih lanjut dan bersifat hipotetis dan fiktif, yaitu norma dasar (grundnorm). "The grundnorm is not constitution, it is simply the presuppotion, demanded by theory, that this constitution ought to be obeyed" (Dias, 1985: 365).

Norma dasar merupakan norma tertinggi dalam suatu sistem norma tersebut tidak lagi dibentuk oleh suatu norma yang lebih tinggi lagi, tetapi norma dasar itu ditetapkan terlebih dahulu oleh masyarakat sebagai norma dasar yang merupakan gantungan bagi norma-norma yang berada di bawahnya, sehingga suatu norma dasar itu dikatakan pre-supposed (Farida, 2010: 41).

Menurut Kelsen suatu norma hukum itu selalu bersumber dan berdasar pada norma yang di atasnya, tetapi ke bawah norma hukum itu juga menjadi sumber dan menjadi dasar bagi norma yang lebih rendah daripadanya. Dalam hal tata susunan/hierarki sistem norma, norma yang tertinggi (norma dasar) itu menjadi tempat bergantungnya norma-norma di bawahnya, sehingga apabila norma dasar itu berubah akan menjadi rusaklah sistem norma yang ada di bawahnya (Farida, 2010: 41).

Nawiasky mengembangkan teori Kelsen tentang jenjang norma dalam kaitannya dengan norma hukum suatu negara yang menyatakan suatu norma hukum dari negara manapun selalu berlapis-lapis dan berjenjang-jenjang. Norma yang di bawah berlaku, bersumber dan berdasar pada norma yang lebih tinggi, norma yang lebih tinggi berlaku, bersumber dan berdasar pada suatu norma yang tertinggi yang disebut norma dasar. Sebagai murid Kelsen, teori yang dikembangkan Nawiasky selain norma itu berlapis-lapis dan berjenjang-jenjang, norma hukum dari suatu negara itu juga berkelompok-kelompok, dan pengelompokan norma hukum dalam suatu negara itu terdiri atas empat kelompok besar antara lain (Farida, 2010: 41):

Staatsfundamentalnorm (norma
fundamental negara);

b. Staatsgrundgesetz (aturan dasar/aturan pokok negara);

c. Formell gesetz (undang-undang "formal");

d. Verordnung \& Autonome satzung (aturan pelaksana/aturan otonom).

$\begin{array}{ccr}\text { Menurut } & \text { Nawiasky, } & \text { isi } \\ \text { staatsfundamentalnorm } & \text { ialah norma yang }\end{array}$ merupakan dasar bagi pembentukan konstitusi atau undang-undang dasar dari suatu negara (staatsverfassung), termasuk norma pengubahannya. Hakikat hukum suatu staatsfundamentalnorm ialah syarat bagi berlakunya suatu konstitusi atau undang-undang dasar. Ia ada terlebih dulu sebelum adanya konstitusi atau undang-undang dasar (Farida, 2010: 41). Selanjutnya Nawiasky mengatakan norma tertinggi yang oleh Kelsen disebut sebagai norma dasar (basic norm) dalam suatu negara sebaiknya tidak disebut sebagai staatsgrundnorm melainkan staatsfundamentalnorm atau norma fundamental negara. Grundnorm mempunyai kecenderungan untuk tidak berubah atau bersifat tetap, sedangkan di dalam suatu negara norma fundamental negara itu dapat berubah sewaktu-waktu karena adanya pemberontakan, kudeta, dan sebagainya (Farida, 2010: 41).

Indonesia sebagai negara hukum yang menganut ajaran negara berkonstitusi seperti negara-negara modern lainnya, memiliki 
konstitusi tertulis yang disebut UUD NRI 1945. UUD NRI 1945 ini ditempatkan sebagai fundamental law sehingga menjadi hukum dasar atau sumber pembuatan hukum-hukum yang lainnya dan sebagai higher law UUD NRI 1945 merupakan hukum tertinggi dalam tata urutan perundang-undangan Republik Indonesia (Manan, 1993: 41-42). Secara kontekstual dalam sistem hierarki peraturan perundang-undangan dikenal dengan tiga asas mendasar. Adapun tiga asas sebagaimana dimaksud antara lain asas lex superior de rogat lex inferior, lex specialist derogat lex generalis, lex posterior de rogat lex priori (Hamidi et.al., 2012: 19).

Berdasarkan studi ilmu hukum tiga asas sebagaimana dimaksud merupakan pilar penting dalam memahami konstruksi hukum perundangundangan di Indonesia secara detail dapat dijelaskan bahwa (Hamidi et.al., 2012: 19):

a. Asas lex superior de rogat lex inferior, peraturan yang lebih tinggi akan mengesampingkan peraturan yang lebih rendah apabila mengatur substansi yang sama dan bertentangan.

b. Asas lex specialist derogat lex generalis, peraturan yang lebih khusus akan mengesampingkan peraturan yang umum apabila mengatur substansi yang sama dan bertentangan.

c. Asas lex posterior de rogat lex priori, peraturan yangbaruakan mengesampingkan peraturan yang lama.

Dengan demikian, dalam setiap pembentukan peraturan perundang-undangan harus memperhatikan sistem hierarki peraturan perundang-undangan, sehingga tercipta keharmonisan antara peraturan perundang- undangan yang dibentuk dengan berbagai peraturan perundang-undangan yang lebih tinggi maupun yang setara. Dalam hal ini, UUD NRI 1945 dijadikan sebagai hukum dasar dalam peraturan perundang-undangan.

UUD NRI 1945 sebagai hukum dasar peraturan perundang-undangan mengatur tentang kewenangan daerah untuk mengatur dan mengurus sendiri urusannya, dalam Pasal 18 ayat (2) UUD NRI 1945 disebutkan bahwa pemerintahan daerah provinsi, daerah kabupaten, dan kota mengatur dan mengurus sendiri urusan pemerintahan menurut asas otonomi dan tugas pembantuan (Asshiddiqie, 2009: 58). Lebih lanjut Pasal 18 ayat (6) menegaskan pemerintahan daerah berhak menetapkan peraturan daerah dan peraturan-peraturan lain untuk melaksanakan otonomi dan tugas pembantuan (Asshiddiqie, 2009: 58).

Berlakunya prinsip otonomi dalam negara Indonesia yang membagi kewenangan antara pusat dan daerah diharapkan segala urusan baik yang bersifat wajib ataupun pilihan dapat dilaksanakan sesuai dengan kewenangan masingmasing yang diberikan oleh Undang-Undang Nomor 23 Tahun 2014 tentang Pemerintahan Daerah. Kewenangan daerah dalam pelaksanaan otonomi ini telah diisyaratkan oleh UndangUndang Nomor 23 Tahun 2014 tentang Pemerintahan Daerah di dalam penjelasan umum disebutkan bahwa daerah sebagai satu kesatuan masyarakat hukum yang mempunyai otonomi, berwenang mengatur dan mengurus daerahnya sesuai aspirasi dan kepentingan masyarakatnya sepanjang tidak bertentangan dengan tatanan hukum nasional dan kepentingan umum.

Dalam rangka memberikan ruang yang lebih luas kepada daerah untuk mengatur dan 
mengurus kehidupan warganya maka pemerintah pusat dalam membentuk kebijakan harus memperhatikan kearifan lokal dan sebaliknya daerah ketika membentuk kebijakan daerah baik dalam bentuk peraturan daerah maupun kebijakan lainnya hendaknya juga memperhatikan kepentingan nasional. Dengan demikian akan tercipta keseimbangan antara kepentingan nasional yang sinergis dan tetap memperhatikan kondisi, kekhasan, dan kearifan lokal dalam penyelenggaraan pemerintahan secara keseluruhan (Penjelasan Undang-Undang Nomor 23 Tahun 2014). Daerah melaksanakan otonomi daerah yang berasal dari kewenangan presiden yang memegang kekuasaan pemerintahan.

Mengingat tanggung jawab akhir penyelenggaraan pemerintahan ada di tangan presiden, maka konsekuensi logisnya kewenangan untuk membatalkan peraturan daerah ada di tangan presiden. Adalah tidak efisien apabila presiden yang langsung membatalkan peraturan daerah. Presiden melimpahkan kewenangan pembatalan peraturan daerah provinsi kepada Menteri sebagai pembantu presiden yang bertanggung jawab atas otonomi daerah. Sedangkan untuk pembatalan peraturan daerah kabupaten/kota, presiden melimpahkan kewenangannya kepada gubernur selaku wakil pemerintah pusat di daerah (Penjelasan Undang-Undang Nomor 23 Tahun 2014).

\section{Perkembangan Kewenangan Pengujian Peraturan Perundang-undangan}

Dalam konteks ilmu perundang-undangan telah dikenal istilah hak menguji (toetsingrecht) dan juga dikenal istilah Judicial Review (Sinamo, 2016: 157). Jika diartikan secara etimologis dan terminologis, toetsingrecht berarti hak menguji terhadap peraturan perundang-undangan khususnya undang-undang dan peraturan lain di bawah undang-undang, sebaliknya judicial review berarti peninjauan terhadap peraturan perundang-undangan oleh lembaga pengadilan (Sinamo, 2016: 157). Sehingga pada dasarnya menurut Fatmawati (2005: 5) kedua istilah tersebut mengandung arti yang sama, yaitu kewenangan untuk menguji atau meninjau.

Perbedaannya adalah dalam istilah judicial review sudah secara spesifik ditentukan bahwa kewenangan tersebut dimiliki oleh pelaksana lembaga pengadilan (Fatmawati, 2005: 5). Huda (2009: 115) menyatakan istilah "hak menguji" berbeda dengan "judicial review." Kalau kita berbicara mengenai hak menguji, orientasinya ialah ke Kontinental Eropa (Belanda), sedangkan judicial review orientasinya ialah ke Amerika Serikat. Walau tujuannya sama, dalam perkembangan selanjutnya apa yang dilaksanakan oleh negara-negara Eropa yang menganut sistem civil law berbeda dengan negara-negara yang menganut sistem common law (Huda, 2009: 115).

Dalam sejarah konstitusi dan peraturan perundang-undangan kita, pemikiran mengenai pengujian inipernahdilontarkanoleh Mohammad Yamin pada saat pembahasan rancangan undang-undang dasar di Badan Penyelidik Usaha Persiapan Kemerdekaan Indonesia (BPUPKI). Mohamad Yamin melontarkan pemikiran mengenai perlunya suatu lembaga yang melakukan pengujian konstitusionalitas undang-undang sekaligus mengusulkan agar masuk dalam rumusan rancangan undangundang dasar yang tengah disusun (Natabaya, 2008: 185-186).

Mohammad Yamin membicarakan tentang alat perlengkapan negara Indonesia yang 
disebutnya dengan enam kekuasaan (the six powers of the Republic of Indonesia), khusus tentang Balai Agung dan Mahkamah Tinggi mengatakan (Rauta, 2016: 85): Mahkamah inilah yang setinggi-tingginya sehingga dalam membanding undang-undang, maka Balai Agung inilah yang akan memutus apakah sejalan dengan hukum adat, syariah, dan UndangUndang Dasar. Namun gagasan Mohammad Yamin tersebut ditolak oleh Soepomo dengan alasan lembaga ini tidak sesuai dengan sistem berpikir undang-undang dasar yang saat itu disusun atas dasar prinsip supremasi parlemen dengan menempatkan MPR sebagai Lembaga Negara Tertinggi (Natabaya, 2008: 185-186).

Soepomo menambahkan argumentasi bahwa kondisi dari negara Indonesia diawal kemerdekaan yang belum memiliki sarjana hukum yang banyak dan memiliki pengalaman dalam judicial review, sehingga keputusannya saat itu Mahkamah Agung tidak diberikan kewenangan untuk menguji undang-undang terhadap undang-undang dasar (Farida, tt: 1.7). Dengan perkataan lain kewenangan menguji undangundang terhadap undang-undang dasar maupun peraturan perundang-undangan lainnya terhadap undang-undang tidak dicantumkan dalam UUD NRI 1945 sebelum perubahan.Lebih lanjut Farida menyatakan bahwa sesuatu yang menarik untuk menjadi sejarah dalam ketatanegaraan yang pernah ada di Indonesia adalah pada saat konstitusi RIS berlaku, pengujian undang-undang terhadap undang-undang dasar sempat dikenal, walaupun dengan batasan hanya pada pengujian terhadap undang-undang negara bagian kepada konstitusi sebagaimana diatur pada Pasal 156, Pasal 157, dan Pasal 158 Konstitusi RIS.

Setelah berlakunya kembali UUD NRI 1945 melalui Dekrit Presiden 5 Juli 1959, pengujian terhadap undang-undang juga tidak diatur dan dianut dalam sistem ketatanegaraan Indonesia. Dalam kurun 1970-1998 pengujian peraturan perundang-undangan dalam perspektif pembagian kekuasaan yang dianut oleh UUD NRI 1945, tidak mengenal pengujian undang-undang terhadap undang-undang dasar, tetapi pengujian peraturan di bawah undang-undang. Hal ini didasarkan pada perolehan kekuasaan di masing-masing lembaga negara yang menurut UUD NRI 1945 diberikan atas dasar delegasi kewenangan dari MPR sebagai pemegang kedaulatan rakyat (Hoesein, 2009: 304).

Kekuasaan negara yang timbul (sebelum Amandemen UUD Tahun 1945:sic) pada dasarnya bermuara pada MPR, dan MPR selanjutnya membagi-bagi kekuasaan tersebut kepada lembaga negara untuk dilaksanakan dalam rangka menjalankan amanat UUD NRI 1945 (Hoesein, 2009: 304). Lebih lanjut Hoesein (2009: 304305) menyatakan bahwa kewenangan yang timbul dan dilekatkan pada lembaga negara, pada hakikatnya kewenangan-kewenangan yang secara eksplisit diserahkan kepada badan atau lembaga negara yang bersangkutan, seperti kewenangan di bidang kehakiman diserahkan kepada lembaga Mahkamah Agung dan badan-badan peradilan di bawahnya.

Hoesein (2009: 305) menyatakan pengujian peraturan perundang-undangan memiliki posisi, tugas, dan fungsi yang sangat penting dalam perspektif ketatanegaraan Indonesia pasca perubahan UUD NRI 1945. Dalam hubungan ini pengujian peraturan perundang-undangan merupakan kontrol normatif terhadap segala bentuk produk hukum sesuai dengan tingkatan atau hierarki normatifnya, sehingga dominasi mayoritas dapat dihindari dan rasa keadilan serta kebenaran dapat ditegakkan oleh lembaga yang berwibawa (Hoesein, 2009: 305). 
Seiring dengan dilakukannya perubahan terhadap UUD NRI 1945 pada tahun 1999 sampai dengan 2002. Kewenangan pengujian peraturan perundang-undangan, oleh UUD NRI 1945 diberikan kepada lembaga Mahkamah Konstitusi untuk menguji undang-undang terhadap undangundang dasar dan Mahkamah Agung untuk menguji peraturan perundang-undangan di bawah undang-undang.

\section{Pengujian terhadap Peraturan Perundang-Undangan di Bawah Undang-Undang}

Sebagai sebuah sistem peraturan perundang-undangan, Soebechi (2012: 180) menyatakan bahwa kesatuan tatanan hukum seharusnya tidak ada pertentangan antara norma hukum satu sama lainnya. Dalam praktiknya, tidak dapat dipungkiri bahwa pertentangan antara norma hukum sering terjadi.

Menurut Kelsen, tidak ada jaminan absolut bahwa norma yang lebih sesuai dengan norma yang lebih tinggi. Hal tersebut dapat terjadi karena organ hukum yang berwenang membuat norma hukum menciptakan norma-norma yang bertentangan (Soebechi, 2012: 180).

Antara satu norma hukum dengan norma hukum lainnya bahwa dimungkinkan terjadi ketidaksamaan (ketidakharmonisan:sic), dalam hal ini Kelsen menyebutnya dengan terjadinya konflik antar norma hukum dari berbagai tingkatan (Soebechi, 2012: 180). Untuk menghindari terjadinya konflik antar norma hukum (disharmoni antar norma hukum) dalam hal ini peraturan perundang-undangan, dapat dilakukan sebelum atau sesudah peraturan perundang-undangan tersebut diundangkan. Upaya yang dilakukan sebelum peraturan perundang-undangan tersebut diundangkan adalah dengan melakukan seluruh rangkaian proses pembentukan peraturan perundangundangan yang berpedoman pada asas-asas pembentukan peraturan perundang-undangan yang baik maupun asas materi muatan peraturan perundang-undangan. Sedangkan upaya yang dapat dilakukan setelah peraturan perundangundangan tersebut diberlakukan adalah melalui permohonan pengujian peraturan perundangundangan kepada lembaga kehakiman.

Sekalipun pengujian terhadap peraturan perundang-undangan sebenarnya tidak masuk dalam definisi pembentukan peraturan perundangundangan dalam Undang-Undang Nomor 12 Tahun 2011 tentang Pembentukan Peraturan Perundang-undangan, namun mengingat adanya kebutuhan hukum, masukan, keresahan, dan keberatan sebagian besar pemangku kepentingan terkait dengan pembatalan dan/atau pencabutan peraturan perundang-undangan di bawah UU, terutama peraturan daerah provinsi dan/atau peraturan daerah kabupaten/kota yang dibatalkan dan atau dicabut dengan perpres atau permendagri, maka substansi mengenai uji materi peraturan perundang-undangan di bawah undang-undang diatur dalam Undang-Undang Nomor 12 Tahun 2011 (Yani, 2013: 74-75). Lebih lanjut Yani (2013) menyatakan bahwa substansi uji materiil atas peraturan perundang-undangan sebagaimana dimaksud dalam Pasal 9 Undang-Undang Nomor 12 Tahun 2011 dapat disebut sebagai terobosan hukum, sebab pengujian peraturan perundangundangan terintegrasi dalam sistem pembentukan peraturan perundang-undangan sebagaimana dimaksud dalam Pasal 9 Undang-Undang Nomor 12 Tahun 2011.

Ketentuan tentang uji materiil atas peraturan perundang-undangan di bawah undang- 
undang paling tidak menjawab kebutuhan untuk menyelesaikan masalah uji materiil secara benar berdasarkan konstitusi, serta harapan agar ke depan hal-hal yang dianggap bertentangan atau tidak sesuai dengan kebijakan regulasi yang diatur dalam peraturan perundang-undangan di bawah undang-undang hanya dapat dicabut dan/ atau dibatalkan oleh Mahkamah Agung (Yani, 2013: 74-75). Ketentuan tersebut berdasarkan amanat Pasal 24A UUD NRI 1945 yang secara tegas menentukan bahwa pengujian peraturan perundang-undangan di bawah undang-undang merupakan kewenangan Mahkamah Agung, yaitu lembaga yudikatif bukan eksekutif (Yani, 2013: 74-75).

Berdasarkan kewenangan yang diberikan oleh ketentuan Pasal 24A UUD NRI 1945, Mahkamah Agung berwenang menguji peraturan pemerintah, peraturan presiden, peraturan daerah provinsi dan peraturan daerah kabupaten/kota yang secara hierarki berada di bawah undangundang (Pasal 7 ayat (1) Undang-Undang Nomor 12 Tahun 2011) dan peraturan perundangundangan sebagaimana dimaksud dalam Pasal 8 ayat (1) Undang-Undang Nomor 12 Tahun 2011, yang masing-masing berbunyi sebagai berikut:

"Jenis dan hierarki peraturan perundangundangan terdiri atas:

a. Undang-Undang Dasar Negara Republik Indonesia Tahun 1945;

b. Ketetapan Majelis Permusyawaratan Rakyat;

c. Undang-Undang/Peraturan Pemerintah Pengganti;

d. Peraturan Pemerintah;

e. Peraturan Presiden;

f. Peraturan Daerah Provinsi; dan

g. Peraturan Daerah Kabupaten/Kota.'
Pasal 8 ayat (1) Undang-Undang Nomor 12 Tahun 2011 menyebutkan bahwa:

"Jenis peraturan perundang-undangan selain sebagaimana dimaksud dalam Pasal 7 ayat (1) mencakup peraturan yang ditetapkan oleh Majelis Permusyawaratan Rakyat, Dewan Perwakilan Rakyat, Dewan Perwakilan Daerah, Mahkamah Agung, Mahkamah Konstitusi, Badan Pemeriksa Keuangan, Komisi Yudisial, Bank Indonesia, Menteri, badan, lembaga, atau komisi yang setingkat yang dibentuk dengan undang-undang atau pemerintah atas perintah Undang-Undang, Dewan Perwakilan Rakyat Daerah Provinsi, Gubernur, Dewan Perwakilan Rakyat Daerah Kabupaten/Kota, Bupati/Wali kota, Kepala Desa atau yang setingkat."

Penjabaran lebih lanjut mengenai kewenangan pengujian oleh Mahkamah Agung diatur dalam Pasal 20 ayat (2) huruf b Undang-Undang Nomor 48 Tahun 2009 tentang Kekuasaan Kehakiman yang berbunyi: Mahkamah Agung berwenang menguji peraturan perundang-undangan di bawah undang-undang terhadap undang-undang (Ketentuan ini mengatur mengenai hak uji Mahkamah Agung terhadap peraturan perundang-undangan yang lebih rendah dari undang-undang.

Hak uji dapat dilakukan baik terhadap materi muatan ayat, pasal, dan/atau bagian dari peraturan perundang-undangan yang bertentangan dengan peraturan perundangundangan yang lebih tinggi maupun terhadap pembentukan peraturan perundang-undangan). Instrumen yang dijadikan batu uji dalam pengujian peraturan perundang-undangan di bawah undang-undang adalah undang-undang dan peraturan perundang-undangan yang lebih tinggi dari peraturan perundang-undangan yang diuji. 


\section{METODE}

Metode yang digunakan dalam tulisan ini adalah metode penelitian hukum yuridis normatif. Penelitian hukum normatif yaitu pendekatan yang dilakukan berdasarkan bahan hukum utama dengan cara menelaah teori-teori, konsep-konsep asas-asas hukum, norma, kaidah dari peraturan perundang-undangan, putusan pengadilan, perjanjian serta.

Mengambil istilah Dworkin, penelitian semacam ini juga disebut dengan istilah penelitian doktrinal (doctrinal research) yaitu penelitian yang menganalisis hukum, baik yang tertulis di dalam buku (law as it is written in the book). Dalam penelitian ini bahan kepustakaan dan studi dokumen dijadikan sebagai bahan utama.

Adapun sifat penelitian yang dipergunakan dalam tulisan ini adalah preskriptif, berpegang pada karakteristik ilmu hukum sebagai ilmu terapan, preskripsi yang diberikan di dalam kegiatan penelitian hukum harus dapat dan mungkin untuk diterapkan (Marzuki, 2011: 251). Oleh karena itu yang dihasilkan oleh penelitian hukum, sekalipun bukan asas hukum yang baru atau teori baru, paling tidak argumentasi baru (Marzuki, 2011: 251).

\section{HASIL DAN PEMBAHASAN}

\section{A. Kewenangan Pembatalan Peraturan} Daerah dan Peraturan Kepala Daerah Pasca Putusan Nomor 137/PUUXIII/2015 dan Nomor 56/PUU-XIV/2016

Ketentuan Pasal 18 ayat (2) UUD NRI 1945 menyebutkan bahwa pemerintahan daerah provinsi, daerah kabupaten, dan kota mengatur dan mengurus sendiri urusan pemerintahan menurut asas otonomi dan tugas pembantuan. Berlakunya prinsip otonomi dalam negara Indonesia yang membagi kewenangan antara pusat dan daerah diharapkan segala urusan baik yang bersifat wajib ataupun pilihan dapat dilaksanakan sesuai dengan kewenangan masing-masing yang diberikan oleh Undang-Undang Nomor 23 Tahun 2014 tentang Pemerintahan Daerah.

Kewenangan daerah dalam pelaksanaan otonomi ini telah diisyaratkan oleh UndangUndang Nomor 23 Tahun 2014 tentang Pemerintahan Daerah. Dalam penjelasan umum disebutkan bahwa daerah sebagai satu kesatuan masyarakat hukum yang mempunyai otonomi berwenang mengatur dan mengurus daerahnya sesuai aspirasi dan kepentingan masyarakatnya sepanjang tidak bertentangan dengan tatanan hukum nasional dan kepentingan umum.

Dalam rangka memberikan ruang yang lebih luas kepada daerah untuk mengatur dan mengurus kehidupan warganya maka pemerintah pusat dalam membentuk kebijakan harus memperhatikan kearifan lokal dan sebaliknya daerah ketika membentuk kebijakan daerah baik dalam bentuk peraturan daerah maupun kebijakan lainnya hendaknya juga memperhatikan kepentingan nasional. Dengan demikian akan tercipta keseimbangan antara kepentingan nasional yang sinergis dan tetap memperhatikan kondisi, kekhasan, dan kearifan lokal dalam penyelenggaraan pemerintahan secara keseluruhan.

Urusan pemerintahan dibagi atas tiga antara lain: urusan pemerintahan absolut, konkuren, dan umum. Urusan pemerintahan yang konkuren adalah urusan pemerintahan yang dibagi antara pemerintah pusat, daerah provinsi dan daerah kabupaten/kota. Urusan pemerintahan konkuren ini dibagi antara lain yang bersifat wajib dan 
pilihan untuk dilaksanakan oleh pemerintahan daerah dalam bentuk peraturan daerah. Situasi ini membuat peraturan daerah makin mempunyai kedudukan yang strategis dalam kehidupan berbangsa dan bernegara atau dengan kata lain peran peraturan daerah dalam melaksanakan urusan pemerintahan menjadi sangat besar.

Kedudukan yang strategis dari peraturan daerah dalam menjalankan urusan pemerintahan dapat menjadi baik jika pembentukan peraturan daerah tersebut dilakukan dengan baik dan menjadi bumerang jika dilakukan dengan tidak baik (Pakpahan, 2010: 5). Selain mempunyai kedudukan yang strategis, peraturan daerah juga mempunyai berbagai fungsi yaitu (DJPP Kemenkum dan HAM RI, 2011: 9):

1. Sebagai instrumen kebijakan untuk melaksanakan otonomi daerah dan tugas pembantuan sebagaimana diamanatkan dalam UUD NRI 1945 dan UndangUndang tentang Pemerintahan Daerah;

2. Merupakan peraturan pelaksanaan dari peraturan perundang-undangan yang lebih tinggi. Dalam fungsi ini, peraturan daerah tunduk pada ketentuan hierarki peraturan perundang-undangan. Dengan demikian peraturan daerah tidak boleh bertentangan dengan peraturan perundang-undangan yang lebih tinggi;

3. Sebagai penampung kekhususan dan keragaman daerah, namun dalam pengaturannya tetap dalam koridor Negara Kesatuan Republik Indonesia yang berlandaskan Pancasila dan UUD NRI 1945;

4. Sebagai alat pembangunan dalam meningkatkan kesejahteraan daerah.
Selain mempunyai kedudukan strategis dan berbagai fungsi, peraturan daerah juga mempunyai materi muatan tersendiri. Menurut Soehino, materi yang dapat diatur dalam peraturan daerah meliputi:

1. Materi-materi atau hal-hal yang memberi beban kepada penduduk, misalnya pajak daerah dan retribusi daerah;

2. Materi-materi atau hal-hal yang mengurangi kebebasan penduduk, misalnya mengadakan larangan-larangan dan kewajiban-kewajiban yang biasanya disertai dengan ancaman atau sanksi pidana;

3. Materi-materi atau hal-hal yang membatasi hak-hak penduduk, misalnya penetapan garis sepadan;

4. Materi-materi atau hal-hal yang telah ditentukan dalam peraturan perundangundangan yang sederajat dan tingkatannya lebih tinggi, harus diatur dengan peraturan daerah (Soehino, 1997: 8).

Secara normatif, materi muatan peraturan daerah dapat dilihat dalam ketentuan Pasal 14 Undang-Undang Nomor 12 Tahun 2011 tentang Pembentukan Peraturan Perundang-undangan. Pada pasal tersebut dijelaskan bahwa materi muatan peraturan daerah provinsi maupun peraturan daerah kabupaten/kota berisi materi muatan dalam rangka penyelenggaraan otonomi daerah dan tugas pembantuan serta menampung kondisi khusus daerah dan/atau penjabaran lebih lanjut peraturan perundang-undangan yang lebih tinggi. Selanjutnya Sihombing \& Marwan (2017: 137) menguraikan bahwa:

"Materi muatan dalam rangka penyelenggaraan otonomi daerah dan 
tugas pembantuan mengandung makna bahwa pembentukan peraturan daerah harus didasarkan pada pembagian urusan antara pemerintah, pemerintah provinsi dan pemerintah kabupaten/kota sebagaimana diatur dalam Undang-Undang Nomor 23 Tahun 2014 tentang Pemerintahan Daerah dan Peraturan perundang-undangan lainnya. Berkaitan dengan materi muatan dalam rangka menampung kondisi khusus daerah, mengandung makna bahwa peraturan daerah sebagai peraturan yang mengabstraksi nilai-nilai masyarakat di daerah yang berisi materi muatan nilai-nilai yang diidentifikasi sebagai kondisi khusus daerah. Berkaitan dengan penjabaran lebih lanjut peraturan perundang-undangan yang lebih tinggi bermakna bahwa secara yuridis pembentukan peraturan daerah bersumber kepada peraturan perundangundangan yang lebih tinggi. Dengan kata lain pembentukan peraturan daerah harus berdasarkan pendelegasian dari peraturan perundang-undangan yang lebih tinggi."

Dalam ketentuan Pasal 236 UndangUndang Nomor 23 Tahun 2014 tentang Pemerintahan Daerah menentukan bahwa materi muatan peraturan daerah adalah sebagai berikut:

1. Untuk menyelenggarakan otonomi daerah dan tugas pembantuan, daerah membentuk peraturan daerah.

2. Peraturan daerah sebagaimana dimaksud pada ayat (1) dibentuk oleh DPRD dengan persetujuan bersama kepala daerah.

3. Peraturan daerah sebagaimana dimaksud pada ayat (1) memuat materi muatan:

a. Penyelenggaraan otonomi daerah dan tugas pembantuan; dan

b. Penjabaran lebih lanjut ketentuan peraturan perundang-undangan yang lebih tinggi.

4. Selain materi muatan sebagaimana dimaksud pada ayat (3) peraturan daerah dapat memuat materi muatan lokal sesuai dengan ketentuan peraturan perundangundangan.

Materi muatan peraturan kepala daerah berdasarkan ketentuan Pasal 246 Undang-Undang Nomor 23 Tahun 2014 adalah materi untuk melaksanakan peraturan daerah atau atas kuasa peraturan perundang-undangan. Kewenangan pemerintah daerah dalam menetapkan peraturan daerah dan peraturan-peraturan lain (termasuk peraturan kepala daerah) telah diakui secara konstitusional. Akan tetapi, Sabarno (2007: 197) menyatakan bahwa pembentukan peraturan daerah tidak dapat bersandarkan pada kewenangannya sendiri, karena daerah berada pada kuasa lingkungan hukum publik nasional. Dalam pembentukannya telah ditetapkan serangkaian asas meliputi kejelasan tujuan, kelembagaan atau organ pembentuk yang tepat, kesesuaian antara jenis dan materi muatan, dapat dilaksanakan, kedayagunaan dan kehasilgunaan, kejelasan rumusan serta keterbukaan. Di samping itu juga, tidak boleh bertentangan dengan peraturan perundang-undangan yang lebih tinggi.

Semua parameter tersebut tentunya bertujuan agar konsep otonomi daerah berjalan pada jalur yang telah ditetapkan, semakin mendekatkan pelayanan pemerintah daerah kepada masyarakat dan yang terpenting tidak mengancam Negara Kesatuan Republik Indonesia. Untuk menjamin agar peraturan daerah maupun peraturan kepala daerah tetap dalam kerangka sistem hukum nasional maka dimungkinkan untuk melakukan pembatalan peraturan dimaksud, apabila bertentangan dengan parameter yang telah ditentukan dalam peraturan perundang-undangan. 
Pengaturan mengenai pembatalan peraturan daerah dan peraturan kepala daerah dapat ditemui dalam rumusan ketentuan Bab IX Bagian Ketiga Pasal 249-252 Undang-Undang Nomor 23 Tahun 2014, dalam ketentuan tersebut dinyatakan bahwa peraturan daerah maupun peraturan kepala daerah dilarang bertentangan dengan ketentuan peraturan perundang-undangan yang lebih tinggi, kepentingan umum, dan/atau kesusilaan. Apabila peraturan daerah maupun peraturan kepala daerah bertentangan dengan ketentuan dimaksud, maka gubernur sebagai wakil pemerintah pusat dapat membatalkan peraturan daerah atau peraturan kepala daerah kabupaten/kota, dan Menteri Dalam Negeri dapat membatalkan peraturan daerah atau peraturan kepala daerah provinsi.

Peraturan daerah atau peraturan kepala daerah kabupaten/kota yang bertentangan dengan ketentuan peraturan perundang-undangan yang lebih tinggi, kepentingan umum, dan/atau kesusilaan tidak dibatalkan oleh gubernur, maka Menteri membatalkan peraturan daerah atau peraturan kepala daerah kabupaten/kota tersebut. Adapun pembatalan peraturan daerah provinsi dan peraturan gubernur ditetapkan dengan keputusan Menteri dan pembatalan peraturan daerah kabupaten/kota dan peraturan bupati/ wali kota ditetapkan dengan keputusan gubernur sebagai wakil pemerintah pusat.

\section{Selanjutnya dalam ketentuan Bab XI} Peraturan Menteri Dalam Negeri Nomor 80 Tahun 2015 tentang Pembentukan Produk Hukum Daerah disebutkan bahwa dalam hal peraturan daerah provinsi atau peraturan gubernur setelah ditetapkan, dalam jangka waktu tujuh hari setelah ditetapkan harus disampaikan kepada Menteri.

Direktur Jenderal Otonomi Daerah atas nama Menteri Dalam Negeri membentuk tim pembatalan peraturan daerah provinsi dan peraturan gubernur yang anggotanya terdiri atas komponen lingkup Kementerian Dalam Negeri dan Kementerian terkait sesuai kebutuhan. Demikian pula halnya dengan peraturan daerah kabupaten/kota dan peraturan kepala daerah setelah ditetapkan dalam jangka waktu tujuh hari setelah ditetapkan harus disampaikan kepada gubernur, sekretaris daerah atas nama gubernur membentuk tim pembatalan peraturan daerah kabupaten/kota dan peraturan bupati/wali kota yang keanggotaannya terdiri atas komponen lingkup perangkat daerah dan instansi terkait sesuai kebutuhan.

Penggunaan istilah tim pembatalan peraturan daerah maupun peraturan kepala daerah sebagaimana dimaksud dalam Permendagri Nomor 80 Tahun 2015 menurut penulis tidaklah tepat, mengingat tugas dari tim pembatalan adalah untuk melakukan kajian terhadap peraturan daerah maupun peraturan kepala daerah yang tidak semuanya berujung pada pembatalan.

Hasil kajian tim pembatalan peraturan daerah atau peraturan kepala daerah dapat berupa pernyataan tidak bertentangan dengan peraturan perundang-undangan yang lebih tinggi, kepentingan umum, dan/atau kesusilaan dan dapat pula berupa pernyataan bertentangan peraturan perundang-undangan yang lebih tinggi, kepentingan umum, dan/atau kesusilaan.

Permendagri Nomor 80 Tahun 2015 ini juga mengatur mengenai instrumen pembatalan peraturan daerah dan peraturan kepala daerah melalui Keputusan Gubernur atau Keputusan Menteri. Pembatalan peraturan daerah dan peraturn kepala daerah melalui instrumen Keputusan Gubernur atau Keputusan Menteri patut dianggap bertentangan dengan rezim peraturan perundang-undangan yang ada di 
Indonesia, hal ini sejalan dengan Huda (2008) menyatakan karena peraturan daerah itu termasuk kategori peraturan yang hierarkinya berada di bawah undang-undang, maka dapat timbul penafsiran bahwa pemerintah pusat sudah seharusnya tidak diberikan kewenangan oleh undang-undang untuk menilai dan mencabut peraturan daerah sebagaimana diatur oleh Undang-Undang Pemerintahan Daerah.

\section{B. Pembatalan Peraturan Daerah Pasca Putusan Mahkamah Konstitusi}

Telah diuraikan terdahulu, bahwa dalam Putusan Nomor 137/PUU-XIII/2015 menyatakan bahwa frase "peraturan daerah kabupaten/ kota dan" dalam ketentuan Pasal 251 ayat (2) dan (4), frase "peraturan daerah kabupaten/ kota dan/atau" dalam Pasal 251 ayat (3), dan frase "penyelenggara pemerintahan daerah kabupaten/kota tidak dapat menerima keputusan pembatalan peraturan daerah kabupaten/kota dan" Undang-Undang Nomor 23 Tahun 2014 tentang Pemerintahan Daerah bertentangan dengan UUD NRI 1945 dan tidak mempunyai kekuatan hukum mengikat. Dengan demikian baik Menteri Dalam Negeri maupun gubernur tidak lagi berwenang membatalkan peraturan daerah kabupaten/kota.

Pembatalan peraturan daerah harus dilakukan melalui mekanisme judicial review di Mahkamah Agung. Setelah Putusan Nomor 137/ PUU-XIII/2015, Mahkamah Konstitusi pada tanggal 14 Juni 2017 juga mengeluarkan Putusan Nomor 56/PUU-XIV/2016 tentang Pengujian atas Undang-Undang Nomor 23 Tahun 2014 tentang Pemerintahan Daerah. Para pemohon dalam perkara ini kembali mempermasalahkan konstitusionalitas dari ketentuan mengenai pembatalan peraturan daerah baik peraturan daerah provinsi maupun peraturan daerah kabupaten/kota yang diatur di dalam Pasal 251 ayat (1) dan (2) Undang-Undang Nomor 23 Tahun 2014 tentang Pemerintahan Daerah.

Putusan Nomor 56/PUU-XIV/2016 ini sekaligus melengkapi Putusan Nomor 137/PUUXIII/2015, sehingga pemerintah pusat tidak lagi memiliki kewenangan untuk melakukan pembatalan peraturan daerah baik peraturan daerah provinsi maupun peraturan daerah kabupaten/kota. Sekilas, putusan ini telah mengembalikan ruh kewenangan pembatalan peraturan perundang-undangan di bawah undang-undang kepada Mahkamah Agung sebagaimana dicantumkan secara eksplisit dalam ketentuan Pasal 24A UUD NRI 1945. Akan tetapi apabila ditelaah secara mendalam, maka putusan ini justru tidak sepenuhnya mengembalikan kewenangan pembatalan peraturan perundangundangan di bawah undang-undang kepada Mahkamah Agung.

Hal ini dikarenakan putusan Mahkamah Konstitusi hanya berlaku terhadap peraturan daerah provinsi dan peraturan daerah kabupaten/ kota, sedangkan terhadap peraturan kepala daerah (peraturan gubernur serta peraturan bupati/ wali kota) masih tetap dapat dibatalkan oleh Menteri Dalam Negeri maupun gubernur secara berjenjang. Dan bahkan antara pertimbangan dengan putusan dapat dikatakan inkonsisten. Dalam pertimbangan Putusan Nomor 137/PUUXIII/2015 dinyatakan:

“... bahwa pembatalan peraturan daerah kabupaten/kota melalui keputusan gubernur sebagaimana dimaksud dalam Pasal 251 ayat (4) Undang-Undang Pemerintah Daerah, menurut Mahkamah Konstitusi tidak sesuai dengan rezim peraturan perundang-undangan yang dianut. Pasal 7 
ayat (1) dan Pasal 8 ayat (2) tidak mengenal keputusan gubernur sebagai salah satu jenis hierarki peraturan perundangundangan maupun Keputusan Menteri sebagai peraturan perundang-undangan. Dengan demikian kedudukan keputusan gubernur bukanlah bagian dari rezim peraturan perundang-undangan, sehingga tidak dapat dijadikan produk hukum untuk membatalkan peraturan daerah kabupaten/kota. Dengan kata lain, menurut Mahkamah Konstitusi terjadi kekeliruan di mana peraturan daerah kabupaten/kota sebagai produk hukum yang berbentuk pengaturan (regeling) dapat dibatalkan dengan keputusan gubernur sebagai bentuk produk hukum yang berbentuk keputusan (beschikking) ..."

“... bahwa oleh karena peraturan kepala daerah merupakan salah satu jenis peraturan perundang-undangan berdasarkan Pasal 8 ayat (2) UndangUndang Nomor 12 Tahun 2011, akan tetapi oleh karena dibentuk hanya oleh kepala daerah sebagai satuan bestuur dalam rangka mengimplementasikan peraturan daerah dan urusan pemerintahan wajib sebagaimana ditentukan dalam UndangUndang Pemerintah Daerah, sehingga dalam Negara Kesatuan pemerintah pusat sebagai satuan bestuur yang lebih tinggi memiliki kewenangan untuk membatalkan peraturan kepala daerah. Pembatalan dan mekanisme pengajuan keberatan pembatalan peraturan kepala daerah dalam Undang-Undang Pemerintah Daerah merupakan bagian dari mekanisme pengawasan dari presiden atau menteri dan gubernur sebagai wakil pemerintah pusat kepada pemerintah daerah atau dengan kata lain sebagai suatu bentuk pengawasan, bukan pengujian peraturan perundangundangan dalam lingkungan bestuur oleh satuan bestuur yang lebih tinggi terhadap satuan bestuur yang lebih rendah ..."

Lebih lanjut dalam Putusan Nomor 56/ PUU-XIV/2016 dengan mendasarkan pada pertimbangan hukum dalam Putusan Nomor 137/PUU-XIII/2015 yang menyatakan bahwa pembatalan peraturan daerah kabupaten/kota melalui executive review adalah bertentangan dengan UUD NRI 1945. Oleh karena dalam Pasal 251 ayat (1) Undang-Undang Nomor 23 Tahun 2014 tentang Pemerintahan Daerah mengatur mengenai pembatalan peraturan daerah provinsi juga melalui executive review maka pertimbangan hukum dalam Putusan Nomor 137/PUU-XIII/2015 berlaku pula pada Putusan Nomor 56/PUU-XIV/2016, sehingga Mahkamah Konstitusi berpendapat bahwa Pasal 251 ayat (1) Undang-Undang Nomor 23 Tahun 2014 tentang Pemerintahan Daerah sepanjang frasa "peraturan daerah provinsi dan" bertentangan dengan UUD NRI 1945.

Mahkamah Konsitusi dalam putusannya, tidak menyatakan bahwa frase "... dan peraturan gubernur ..." dan frase “... peraturan bupatil wali kota sebagaimana dimaksud pada ayat (2) ditetapkan dengan keputusan gubernur sebagai wakil pemerintah pusat" dalam ketentuan Pasal 251 ayat (4) Undang-Undang Nomor 23 Tahun 2014 tidak memiliki kekuatan mengikat.

Selain itu Mahkamah Konstitusi seharusnya juga memutus bahwa frase “... dan peraturan gubernur” dan “... dan peraturan bupati/wali kota" sebagaimana dimaksud dalam ketentuan Pasal 251 ayat (1) dan (2), serta frase "penyelenggara pemerintahan daerah provinsi tidak dapat menerima keputusan pembatalan peraturan daerah provinsi dan peraturan gubernur" dan frase "penyelenggara pemerintahan daerah kabupaten/kota tidak dapat menerima keputusan pembatalan peraturan daerah kabupaten/kota dan peraturan bupatil wali kota" sebagaimana dimaksud pada ayat (7) dan (8) Undang-Undang Pemerintah Daerah bertentangan dengan UUD NRI 1945 dan tidak mempunyai kekuatan hukum mengikat. 
Peraturan bupati/wali kota merupakan salah satu bentuk peraturan perundang-undangan yang memuat norma hukum mengikat secara umum dan ditetapkan oleh lembaga negara atau pejabat yang berwenang melalui prosedur yang ditetapkan dalam peraturan perundang-undangan, selain itu secara hierarki kedudukan peraturan bupati/wali kota berada di bawah undang-undang sebagaimana tercantum dalam ketentuan Pasal 7 ayat (1) dan Pasal 8 ayat (2) Undang-Undang Nomor 12 Tahun 2011 yang berbunyi:

"Jenis peraturan perundang-undangan selain sebagaimana dimaksud dalam Pasal 7 ayat (1) mencakup peraturan yang ditetapkan oleh Majelis Permusyawaratan Rakyat, Dewan Perwakilan Rakyat, Dewan Perwakilan Daerah, Mahkamah Agung, Mahkamah Konstitusi, Badan Pemeriksa Keuangan, Komisi Yudisial, BankIndonesia, Menteri, badan, lembaga, atau komisi yang setingkat yang dibentuk dengan UndangUndang atau Pemerintah atas perintah Undang-Undang, Dewan Perwakilan Rakyat Daerah Provinsi, Gubernur, Dewan Perwakilan Rakyat Daerah Kabupaten/ Kota, Bupati/Wali kota, Kepala Desa atau yang setingkat."

Sehingga, sudah seharusnya pembatalan peraturan gubernur maupun peraturan bupati/ wali kota dilakukan melalui mekanisme judicial review di Mahkamah Agung.

Dalam negara dengan bentuk kesatuan memang sudah sepatutnya pemerintah yang tingkatannya lebih tinggi diberikan kewenangan untuk melakukan pengawasan terhadap regulasi (termasuk peraturan daerah dan peraturan kepala daerah) yang lahir di daerah. Implementasi dari pengawasan tersebut dapat dilakukan dengan melakukan pembinaan kepada daerah melalui penguatan executive preview atau pengujian terhadap suatu norma hukum sebelum sah mengikat secara umum.
Mengingat proses pembentukan suatu produk hukum daerah membutuhkan waktu, biaya, dan tenaga yang tidak sedikit. Sehingga jauh lebih efektif dan efisien apabila pengujian dilakukan oleh pemerintah pada saat sebelum produk hukum daerah tersebut diundangkan. Hal ini sejalan dengan ruh ketentuan Pasal 24A UUD NRI 1945 yang sama sekali tidak memberikan delegasi kewenangan pengujian terhadap peraturan daerah maupun peraturan kepala daerah kepada lembaga eksekutif.

\section{KESIMPULAN}

Berdasarkan uraian di atas dapat disimpulkan bahwa pasca Putusan Nomor 137/ PUU-XIII/2015 dan Nomor 56/PUU-XIV/2016, Menteri Dalam Negeri maupun gubernur tidak lagi berwenang membatalkan peraturan daerah provinsi dan peraturan daerah kabupaten/kota. Putusan ini tidak serta merta menyelesaikan permasalahan konstitusionalitas kewenangan pengujian terhadap produk hukum daerah yang notabene secara hierarki berada di bawah undang-undang. Hal ini dikarenakan Menteri Dalam Negeri masih tetap dapat membatalkan peraturan gubernur serta gubernur masih dapat membatalkan peraturan bupati/wali kota.

Putusan ini sekilas mengembalikan ruh kewenangan pengujian kepada Mahkamah Agung sebagaimana diamanahkan oleh Pasal 24A UUD NRI 1945, akan tetapi apabila dicermati justru putusan ini tidak benar-benar mendudukkan kewenangan pengujian peraturan perundang-undangan di bawah undang-undang hanya kepada Mahkamah Agung. Seharusnya Mahkamah Konstitusi, menyatakan peraturan kepala daerah tidak lagi dapat dibatalkan oleh pemerintah yang tingkatannya lebih tinggi, 
hal ini dikarenakan peraturan kepala daerah merupakan jenis peraturan perundang-undangan yang mengikat secara umum dan hierarkinya berada di bawah undang-undang, sehingga untuk mengajukan pembatalannya harus melalui proses judicial review di Mahkamah Agung. Adapun pemerintah yang tingkatannya lebih tinggi masih dapat diberikan kewenangan untuk melakukan pengawasan terhadap regulasi (termasuk peraturan daerah dan peraturan kepala daerah) yang lahir di daerah melalui penguatan executive preview atau pengujian terhadap suatu norma hukum sebelum sah mengikat secara umum dengan melibatkan instansi vertikal yang tugas dan fungsinya berkaitan dengan peraturan perundang-undangan (dalam hal ini Kementerian Hukum dan HAM). Hal ini sejalan dengan ruh ketentuan Pasal 24A UUD NRI 1945 yang sama sekali tidak memberikan delegasi kewenangan pengujian terhadap peraturan daerah maupun peraturan kepala daerah kepada lembaga eksekutif.

\section{DAFTAR ACUAN}

Asshiddiqie, J. (2009). Komentar atas UndangUndang Dasar Negara Republik Indonesia Tahun 1945. Jakarta: Sinar Grafika.

Budiputra, I.G.E. (2015). Dualisme pembatalan peraturan daerah provinsi dengan peraturan presiden \& peraturan Menteri Dalam Negeri. Tesis. Bali: PPS Univeritas Udayana.

Dias, R.W.M. (1985), Jurisprudence. Fifth Edition. London: Butterworths.

Direktorat Jenderal Peraturan Perundang-Undangan Kementerian Hukum dan HAM RI [DJPP Kemenkum dan HAM RI]. (2011). Panduan praktis memahami perancangan peraturan daerah. Edisi Kelima. Jakarta: Dirjen Peraturan Perundang-undangan Kemenkum dan HAM.

Farida, M. (2010). Ilmu perundang-undangan: Jenis, fungsi, \& materi muatan. Yogyakarta: Kanisius.

(tt). Modul I: Pengujian peraturan perundang-undangan. Diakses dari http:// repository.ut.ac.id/4116/1/HKUM4404-M1 . pdf

Fatmawati. (2005). Hak menguji (Toetsingrecht) yang dimiliki hakim dalam sistem hukum Indonesia. Jakarta: Rajagrafindo Persada.

Hamidi, J. et.al. (2012). Teori \& hukum perancangan perda. Cetakan Pertama. Malang: Universitas Brawijaya Press (UB Press).

Hoesein, Z.A. (2009). Judicial review di Mahkamah Agung RI. Jakarta: Rajagrafindo Persada.

Huda, N. (2008, Juni). Problematika yuridis di seputar pembatalan perda. Jurnal Konstitusi, 5(1), 4562.

(2009). Hukum pemerintahan daerah. Bandung: Nusa Media.

Manan, B. (1993). Beberapa masalah hukum tata negara Indonesia. Bandung: Alumni.

Marzuki, P.M. (2011). Penelitian hukum, Jakarta: Prenadamedia Group.

Natabaya, H.A.S. (2008). Sistem peraturan perundang-undangan di Indonesia. Jakarta: Konstitusi Press.

Pakpahan, R.H. (2010). Pengujian peraturan daerah oleh lembaga eksekutif \& yudikatif. Tesis. Universitas Sumatera Utara.

Rauta, U. (2016). Konstitusionalitas pengujian peraturan daerah. Yogyakarta: Genta Publishing. 
Sabarno, H. (2007). Memandu otonomi daerah menjaga kesatuan bangsa. Cet. I. Jakarta: Sinar Grafika.

Sihombing, E.N.A.M., \& Marwan, A. (2017). Ilmu perundang-undangan. Medan: Pustaka Prima.

Sinamo, N. (2016). Ilmu perundang-undangan. Jakarta: Jala Permata Aksara.

Soebechi, I. (2012). Judicial review peraturan daerah pajak \& retribusi daerah. Jakarta: Sinar Grafika.

Soehino. (1997). Hukum tata negara, penyusunan \& penetapan peraturan daerah. Yogyakarta: Liberty.

Yani, A. (2013). Pembentukan peraturan perundangundangan yang responsif (Anotasi terhadap UU No. 12 Tahun 2011 tentang Pembentukan Peraturan Perundang-Undangan). Cetakan I. Jakarta: Konstitusi Press. 